Crop Breeding and Applied Biotechnology 14: 154-159, 2014

Brazilian Society of Plant Breeding. Printed in Brazil

\title{
ARTICLE
}

http://dx.doi.org/10.1590/1984-70332014v14n3a23

\section{Morphological effects of induced polyploidy in Dendrobium nobile Lindl. (Orchidaceae)}

Mívia Rosa de Medeiros Vichiato ${ }^{1 *}$, Marcelo Vichiato ${ }^{1}$, Moacir Pasqual $^{2}$, Filipe Almendagna Rodrigues ${ }^{2}$ and Daniel Melo de Castro ${ }^{3}$

Received 26 March 2014

Accepted 14 April 2014

\begin{abstract}
In general, polyploidy in plants causes an increase in the size of vegetative structures. This work aimed to compare diploid plants $(2 n=2 x=38)$ and induced tetraploid plants $(2 n=4 x=76)$ of Dendrobium nobile Lindl. through the evaluation of the morphological characteristics of flowers, leaves and pseudobulbs. We evaluated the parameters height and diameter of pseudobulbs; width and length of leaves and flowers (sepals, petals and labella); and diameter of flowers. The induced polyploidization resulted in the increasing the number of internodes (19.9\%) and floral pieces, with greater height of the flower (4.5\%) and width of the lip (18.5\%) decrease in the number of flowers per pseudobulb (40.9\%) and the diameter of the pseudobulb (64.9\%) and delayed flowering.
\end{abstract}

Key words: Orchid, chromosome doubling, colchicine, tetraploidy.

\section{INTRODUCTION}

Dendrobium nobile Lindl. (olho de boneca), native herbaceous epiphyte of Southeast Asian of cultivation widespread in scientific circles, is considered the most orchid produced and marketed both in Brazil and in the world, occupying a prominent position in the market potted plants (Vichiato et al. 2008, Vilela et al. 2010).

The considerable interest in the genus Dendrobium is due to its wide geographic distribution, growth in different habitats, cultivation and relatively simple, which is mainly due to the large floristic value of their hybrids and significant volume of trade (Vichiato et al. 2007, Vichiato et al. 2008). The value of $D$. nobile depends on the sales of specific visual patterns transferred by genetic inheritance, such as color, size and shape of the flower. Breeding programs for Dendrobium aim at obtaining plants for the market with desirable characteristics, for example, pseudobulbs with high vigor, upright flowers, a large number of flowers and variability of colors and shapes as well as an extended flowering season (Faria et al. 2009). In Brazil, however, there have been few studies on breeding orchids due to the long cycle of plants in the Dendrobium genus, which leads to an average flowering development of three to four years.

Polyploidy can produce desirable characteristics, which translate into increased floral parts, succulence degree, color intensification, durability and resistance of flowers. In the Dendrobium genus, autopolyploidy results in increased floral pieces with larger sizes and widths of petals and/or sepals as well as greater durability of flowering, greater fertility and a decreased number of flowers per pseudobulb (Chaicharoen and Aejew 1981, Chaicharoen 1995, McConnell and Kamemoto 1993, Ketsa et al. 2001, DaoLong et al. 2012). Moreover, autopolyploidy results in a slow growth of the plants (Chaicharoen and Aejew 1981, Vichiato et al. 2007) as well as a greater width and thickness of leaves (Chaicharoen and Aejew 1981, Dao-Long et al. 2012). Furthermore, there is a significant correlation between ploidy level and plant height of Dendrobium (Dao-Long et al. 2012).

The aim of this study was to evaluate the morphological effects of induced polyploidy in Dendrobium nobile Lindl.

\footnotetext{
${ }^{1}$ Prefeitura Municipal de Belo Horizonte, Secretaria Municipal de Meio Ambiente, Avenida Afonso Pena, 4000, Cruzeiro, 30.130-009, Belo Horizonte, MG, Brazil. *E-mail: mivia@ig.com.br

${ }^{2}$ Universidade Federal de Lavras, Departamento de Agricultura, C. P. 3037, 37.200-000, Lavras, MG, Brazil

${ }^{3}$ Universidade Federal do Recôncavo da Bahia, Centro de Ciências Agrárias, Ambientais e Biológicas, Rua Rui Barbosa, 710, Centro, 44.380-000, Cruz das Almas, BA, Brazil
} 
through the comparison of flowers, leaves and pseudobulbs of diploid $(2 \mathrm{n}=2 \mathrm{x}=38)$ and induced tetraploid $(2 \mathrm{n}=4 \mathrm{x}$ $=76)$ plants.

\section{MATERIAL AND METHODS}

\section{Local}

The research was conducted in a greenhouse equipped with shading (providing 50\% shading) by coverage with black polyethylene film (150 microns) in the municipality of Igarapé (lat $20^{\circ} 04^{\prime} 13$ ' S, long $44^{\circ} 18^{\prime} 06^{\prime \prime} \mathrm{W}$ and alt 786 $\mathrm{m}$ asl), Minas Gerais. The region has a humid subtropical climate (Köppen Climate Classification-Geiger: Cwa) and is mountainous.

\section{Genetic material}

Diploid $D$. nobile plants $(2 \mathrm{n}=38$ chromosomes - witnesses and the treatments did not occur in polyploidization) and induced tetraploid plants $(2 \mathrm{n}=4 \mathrm{x}=76$ chromosomes $)$ derived from the work of Vichiato (2007) were used, and these plants were cultivated in polyethylene pots $\left(500 \mathrm{~cm}^{3}\right)$ containing coconut fiber substrate that were maintained on countertops.

\section{Polyploidization}

D. nobile diploid $(2 \mathrm{n}=38$ chromosomes) plants with an average height of $5.0 \mathrm{~cm}$ and 3 leaves were trimmed so that the remaining roots were $1.0-1.5 \mathrm{~cm}$ in length. The plants were completely immersed in an aqueous colchicine solution in $5 \mathrm{~L}$ plastic containers. Constant air bubbling achieved with domestic aquarium aerating pumps was used to prevent plant damage caused by oxygen depletion. Tween-80 $(0.01 \%)$ was added to increase the colchicine efficiency (Vichiato et al. 2007).

The plastic containers were stored at room temperature and protected from light. After the colchicine treatment, the plants were washed thoroughly in running water for 20 minutes and in distilled water for 5 minutes to remove excess colchicine (Vichiato et al. 2007). The plants were then properly identified and planted in black polyethylene pots (volume of $500 \mathrm{~cm}^{3}$ ) containing fern fiber as substrate. The plants were transferred to the greenhouse and set on metal benches where they remained for seven months.

Irrigation was performed three times a week on average according to the conditions of the substrate being moist and were fertilized bi-weekly with $2 \mathrm{~mL}$ of Biofert Plus ${ }^{\circledR}$ fertilizer per plant at a concentration of $5.0 \mathrm{~mL} \mathrm{~L}^{-1}$ through foliar spray (Vichiato et al. 2007).
The determination of ploidy level was performed by counting chromosomes seven months after the beginning of the experiment when polyploidization was induced. An increased number of induced $D$. nobile tetraploid plants was obtained by immersion of the plants in a solution of $0.1 \%$ colchicine for 96 hours.

\section{Cytogenetic analysis}

The determination of ploidy level was performed by counting chromosomes seven months after the beginning of the experiment when polyploidy was induced. One-centimeter apices were extracted from 5 roots of $D$. nobile plants and pretreated in ice water with a temperature close to $0{ }^{\circ} \mathrm{C}$ for 24 hours. After the pretreatment, the roots were fixed in a freshly prepared solution of acetic acid:chloroform:95\% ethanol (1:3:6) at $4{ }^{\circ} \mathrm{C}$ for 24 hours and transferred to $70 \%$ ethanol where they remained stored at $4{ }^{\circ} \mathrm{C}$ in a refrigerator. Subsequently, the material was subjected to conventional crushing techniques and was washed three times in deionized water for a period of 10 minutes. Cell wall hydrolysis was performed using $1 \mathrm{~N} \mathrm{HCl}$ for 30 to 40 minutes depending on the thickness of the root in a water bath at $60^{\circ} \mathrm{C}$. After this stage, the roots were immersed in deionized water for 1 minute for a chilled interruption of the hydrolysis reaction and were subsequently subjected to deionized water at room temperature (Vichiato et al. 2007).

The extraction and fragmentation of the meristem were performed under a stereoscopic microscope using a blade assembly by smashing in $45 \%$ acetic acid. The samples were stained with Giemsa solution with $3 \%$ phosphate buffer (pH 6.8) for 10 minutes, and the samples were mounted on cover slips with an Entellan ${ }^{\circledR}$. The samples were imaged using an Olympus BX 60 microscope under bright field illumination with a $100 \mathrm{X}$ objective (oil immersion) (Vichiato et al. 2007).

\section{Morphological analysis}

Diploid $D$. nobile plants $(2 \mathrm{n}=38$ chromosomes - witnesses and the treatments did not occur in polyploidization) and induced tetraploid D. nobile plants $(2 \mathrm{n}=4 \mathrm{x}=76$ chromosomes) were used seven years after the induction of polyploidization, and these plants were cultivated in polyethylene pots $\left(500 \mathrm{~cm}^{3}\right)$ containing coconut fiber substrate and maintained on countertops.

Irrigation was performed three times a week on average according to the conditions of the substrate being moist and were fertilized bi-weekly with $2 \mathrm{~mL}$ of Biofert Plus ${ }^{\circledR}$ fertilizer per plant at a concentration of $5.0 \mathrm{~mL} \mathrm{~L}^{-1}$ through foliar spray. 
A completely randomized design was used with two treatments and 32 repetitions with one plant per plot totaling 64 plots. The diploid and induced tetraploid $D$. nobile plants were assessed at flowering for the following variables: frequency of flowering, number of flowers per pseudobulb, flower size and lip size (measured with a caliper and expressed in centimeters). The following vegetative characteristics were measured: shoot length (measured with a ruler graduated in millimeters and expressed in inches), pseudobulb diameter (measured with a caliper and expressed in millimeters) and leaf number.

The results of these assessments were submitted to analysis of variance, and the means were compared by Tukey's test at $5 \%$ probability. From these coefficients, we used the analysis of simple correlation between the variable sizes of the flowers and lips.

\section{RESULTS AND DISCUSSION}

\section{Changes in flowering and floral morphology of D. nobile plants}

The first flowering of $D$. nobile diploid plants with normal flowers occurred two years after the conclusion of the polyploidization experiment. Neptune (1984) also found that this species produces flowers in the second year of growth.

Five years after the experimental induction of polyploidy, the $D$. nobile tetraploid plants showed the first flowering with few flowers that had malformed petals, sepals and/ or lips. Anurita and Girjesh (2007) also found a delay in flowering in polyploid plants of Beijo-de-frade (Impatiens balsamina).

The delay in flowering of induced tetraploid $D$. nobile plants may have resulted from a gene dosage doubling. The immediate effect of polyploidy was morphophysiological with increased size of the cells due to a greater nuclear volume. Accordingly, these cells consume more energy and require more time for the duplication of DNA, which leads to a reduction of cell division during development, causing a delay in the mitotic cycle and life cycles as expressed in low biomass production per unit time (Takamura and
Miyajima 1996, Vichiato et al. 2007, Jadrná et al. 2010).

Seven years after the conclusion of the polyploidization experiment, the induced tetraploid $D$. nobile plants visually had normal flowering. In assessing the frequency of flowering plants, the percentage of diploid and tetraploid flowering plants was 96 and $71.875 \%$, respectively.

The number of flowers per pseudobulb also varied among the different ploidy levels. Diploid plants had a higher average number of flowers per pseudobulb (6.6) differing significantly from the tetraploid plants, which had 4.7 flowers per pseudobulb (decrease of $40.85 \%$ ). The decrease in the number of flowers per pseudobulb in $D$. nobile polyploid plants has also been confirmed by Chaicharoen and Aejew (1981) and Chaicharoen (1995).

The diploid and tetraploid plants had flowers with an average duration of 11 days, which was the same duration of wild D. nobile flowers (Faria et al. 2009). In this study, the tetraploid plants had greater flower heights (4.54\%) and lip widths (18.46\%) when compared to diploid flowers (Figure 1 and Table 1). All variables related to floral morphology showed low variability for the coefficient of variation values representing a low degree of variability, which indicated a more homogeneous distribution of variable values around the mean. Thus, concluded that the effect of chromosome doubling in $D$. nobile floral morphology was verified.

Regarding the flower and lip sizes, induced tetraploid plants showed the highest mean values of height and width

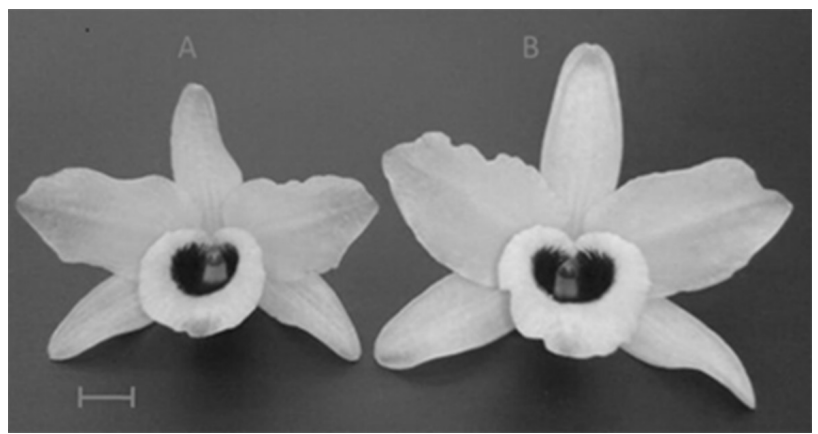

Figure 1. Flowers of Dendrobium nobile Lindl. Form diploid, $2 \mathrm{n}=2 \mathrm{x}=$ 38 (A) and form tetraploid, $2 \mathrm{n}=4 \mathrm{x}=76(\mathrm{~B}) . \mathrm{Bar}=1 \mathrm{~cm}$.

Table 1. Average size of flowers and labella (width and length) of diploid and tetraploid plants of Dendrobium nobile Lindl.

\begin{tabular}{lcccc}
\hline & \multicolumn{3}{c}{ Size of flower } & \multicolumn{2}{c}{ Size of labella } \\
\hline Ploidy level & Width $(\mathrm{cm})$ & Length $(\mathrm{cm})$ & Width $(\mathrm{cm})$ & Length $(\mathrm{cm})$ \\
Diploid & $4.6781 \mathrm{~b}$ & $5.0531 \mathrm{a}$ & $1.5437 \mathrm{~b}$ & $2.1718 \mathrm{a}$ \\
Tetraploid & $4.8906 \mathrm{a}$ & $5.2375 \mathrm{a}$ & $1.8281 \mathrm{a}$ & $2.1968 \mathrm{a}$ \\
\hline C.V. (\%) & 7.36 & 7.22 & 10.93 & 8.53 \\
\hline
\end{tabular}

Means followed by different letters in columns differ according to Tukey's test at $5 \%$ probability. 
of the flower and lip differing significantly from the diploid plants. These data indicated that increasing the width and height of the flower implies an increase in lip size. The positive correlation between the flower length and width is important because orchids are appreciated for the formation of an equilateral triangle by both rounded sepals and petals.

The increase in the $D$. nobile floral piece sizes caused by polyploidization has also been observed by Chaicharoen and Aejew (1981), McConnell and Kamemoto (1993), Chaicharoen (1995), Ketsa et al. (2001) and Dao-Long et al. (2012).

\section{Simple correlation between floral variables}

Table 2 presents a matrix of simple correlations between floral morphology variables of $D$. nobile. By providing the correlation between several variables, this type of analysis is an important indicator of the linearity of the relationship resulting from the treatments. The simple correlations between variables indicated that the variable groups were not independent. Specifically, the variables related to tetraploid D. nobile floral morphology showed strong correlations with the variables related to lip morphology $(0.6<\mathrm{R}<1)$. The correlation between the flower height $(\mathrm{FH})$ and flower width (FW) showed the highest coefficient of linearity. Both the flower height and width showed a positive correlation with lip size and height (0.6862 and 0.6766 , respectively).

The only non-significant correlation was between flower width and lip width ( $p>0.05)$, which suggested that the amendments made by the flower width were not accompanied by changes in the lip width with polyploidy induction.

\section{Changes in vegetative growth}

For the vegetative characteristics evaluated in the control and induced polyploid $D$. nobile plants, only significant differences $(\mathrm{P}<0.5)$ were found for pseudobulb diameter and internode number (Table 3 ). There were no significant differences between the diploid and induced tetraploid plants for the other evaluated vegetative characteristics. This result may be due to the effect of gigas, which are increased vegetative structures that are commonly found in organs that have a highly specific growth pattern, such as flowers and seeds. Therefore, these differences are not always observed between plants with different ploidy levels (Vichiato et al. 2007).

During the development of these plants, there was a tendency for diploidization or polyploidization if the plants were diploid. It is common for a polyploid to undergo diploidization because two or more similar genomes start to behave as diploid over time (Ramsey and Schemske 2002).

\section{Diameter of the pseudobulbs}

The pseudobulb diameter of the control plants was $64.86 \%$ higher than that of the treated plants (Table 2). The pseudobulb of epiphytic orchids is the main storage organ for water, carbohydrates and mineral nutrients (Zimmerman 1990). As the volume of orchid pseudobulbs may vary during growth due to the transfer of stored reserves (Vichiato et al. 2008), there was a significant correlation between the level of ploidy of the plants and the height of Dendrobium, which agreed with the study by Dao-Long et al. (2012). Thus, it can be concluded that the diameter reduction of the tetraploid plant pseudobulbs was due to the induced gene

Table 2. Correlation matrix between variables related to floral morphology of Dendrobium nobile Lindl. tetraploid.

\begin{tabular}{lcccc}
\hline Traits & FH & FW & LH & LW \\
\hline FH & 1 & $0.8351^{* *}$ & $0.6862^{* *}$ & $0.3846^{*}$ \\
FW & & 1 & $0.6766^{* *}$ & 0.3344 \\
LH & & & 1 & $0.4440^{*}$ \\
LW & & & 1 \\
\hline
\end{tabular}

*, ** Significant at $5 \%$ and $1 \%$ probability, respectively; FH: flower height; FW: flower width; LH: lip height; and LW: lip width.

Table 3. Height (H), diameter (D), number of leaves (NL), number of pseudobulb internodes (NPI), length (L) and leaf width (LW) of diploid and tetraploid plants of Dendrobium nobile Lindl.

\begin{tabular}{lcccccc}
\hline Ploidy level & H $(\mathbf{c m})$ & $\mathbf{D}(\mathbf{m m})$ & NL & NPI & L(cm) & LW $(\mathbf{c m})$ \\
\hline Diploid & $24.04 \mathrm{a}$ & $1.22 \mathrm{a}$ & $4.93 \mathrm{a}$ & $10.12 \mathrm{a}$ & $7.63 \mathrm{a}$ & $2.06 \mathrm{a}$ \\
Tetraploid & $26.42 \mathrm{a}$ & $0.74 \mathrm{~b}$ & $4.53 \mathrm{a}$ & $12.13 \mathrm{~b}$ & $7.23 \mathrm{a}$ & $2.01 \mathrm{a}$ \\
\hline C.V. $(\%)$ & 19.83 & 29.25 & 35.41 & 20.74 & 14.31 & 10.39 \\
\hline
\end{tabular}

Means followed by different letters in columns differ according to the Tukey's test at $5 \%$ probability. 
dosage resulting in increased power consumption during development and flowering because the flowers and seeds are organs that have highly specific growth patterns (gigas effect). These increases in cellular energy consumption likely affected the pseudobulbs as they are the storage organs. Greater resistance and plant survival under conditions of water and nutrition stress results in better flower quality (Rech et al. 2010).

\section{Number of internodes}

The number of internodes was influenced by polyploidization (Table 2), and the tetraploid plants showed an increase of $19.86 \%$ in internode number compared to the control plants. The internode number accompanies growth in plant height because internodes directly participate in the process of division and elongation of meristematic cells (Machado et al. 2009). Even though there was no significant difference in pseudobulb height between diploid and tetraploid D. nobile plants, it can be concluded that the addition of polyploidization favored the number of internodes.

The increased number of internodes (region between two nodes) proved to be a morphological variable that is economically viable because the orchid has lateral inflores- cence starting on pseudobulb nodes forming several groups with two or three flowers each (Faria et al. 2009).

\section{Advantages of polyploidy in D. nobile}

For selection of ornamental plants with superior quality, the ornamental features color, size and proportionality of flowers are considered (Cardoso 2010). The tetraploid plants had larger flowers $D$. nobile with labella wider and more rounded when compared with diploid flowers. Whereas the decrease in the number of flowers per pseudobulb of tetraploid plants may be offset by increased floral parts and the number of internodes, polyploidy in $D$. nobile becomes interesting and economically viable, since it results in plants with ornamental qualities satisfactory and competitive market for the flower vase.

\section{CONCLUSIONS}

The induced polyploidization resulted in the following morphological effects a) increasing the number of internodes $(19.9 \%)$ and floral pieces, with greater height of the flower $(4.5 \%)$ and width of the lip (18.5\%) b) decrease in the number of flowers per pseudobulb $(40.8 \%)$ and the diameter of the pseudobulb (64.9\%) and c) delayed flowering.

\section{Efeitos morfológicos da poliplodia induzida em Dendrobium nobile Lindl. (Orchidaceae)}

Resumo - A poliploidia nas plantas ocasiona, geralmente, um aumento em tamanho das estruturas vegetativas. Este trabalho objetivou comparar plantas diploides $(2 n=2 x=38)$ e tetraploides induzidos $(2 n=4 x=76)$ de Dendrobium nobile Lindl., mediante avaliação das características morfológicas de flores, folhas e pseudobulbos. Foram avaliados a altura e o diâmetro dos pseudobulbos e a largura e o comprimento das folhas e flores (comprimento de sépalas, de pétalas, de labelo e diâmetro da flor). A poliploidização induzida em Dendrobium nobile L. resultou no aumento do número de entrenós (19,9\%) e das peças florais, com maior altura da flor (4,5\%) e largura do labelo (18,5\%), na diminuição do número de flores por pseudobulbo (40,85\%) e do diâmetro do pseudobulbo (64,9\%) e no retardo na floração.

Palavras-chave: Orquídea, duplicação cromossômica, colchicina, tetraploidia.

\section{REFERENCES}

Anurita D and Girjesh K (2007) Morphogenetic analysis of colchitetraploids in Impatiens balsamina L. Caryologia 60: 199-202.

Cardoso JC (2010) Laeliocattleya 'Brazilian Girl Rosa': cultivar de orquídea para cultivo em vaso. Horticultura Brasileira 28: 378-381.

Chaicharoen S (1995) Studies on chromosome number, floral and characteristic fertility of diploid and allotetraploid Dendrobium superbiens. Kasetsart Journal: Natural Science 29: 150-157.

Chaicharoen S and Aejew k (1981) Autopolyploidy in Dendrobium phalaenopsis. Science Asia 7: 25-32.

Dao-Long L, Xie Rui-Zhen Z, Yang-Hui L, Mao-Sheng Y and Zhang Zhi-Sheng Z (2012) Relationship between chromosome ploidy and morphology characters in Dendrobium. Acta Botanica BorealiOccidentalia Sinica 10: 143-149.
Faria RT, Takahashi LSA and Lone AB (2009) UEL 6: nova cultivar de Dendrobium. Horticultura Brasileira 27: 114-115.

Jadrná P, Plavcová O and Kobza F (2010) Morphological changes in colchicine-treated Pelargonium $\times$ hortorum L.H. Bailey greenhouse plants. Horticultural Science 37: 27-33.

Ketsa S, Uthairatanakij A and Prayurawong A(2001) Senescence of diploid and tetraploid cut inflorescences of Dendrobium 'Caesar'. Scientia Horticulturae 91: 133-141.

Machado RS, Ribeiro RV, Marchiori PER, Machado DFSP, Machado EC and Landell MG (2009) Respostas biométricas e fisiológicas ao déficit hídrico em cana-de-açúcar em diferentes fases fenológicas. Pesquisa Agropecuária Brasileira 44: 1575-1582.

McConnell JH and Kamemoto H (1993) Morphology and meiotic behavior of three Dendrobium amphidiploids and their diploid counterparts. Hort Science 28: 935-937. 
Neptune WB (1984) The culture of Dendrobium nobile. American Orchid Society Bulletin 53: 462-468.

Ramsey J and Schemske DW (2002) Neopolyploidy in flowering plants. Annual Review of Ecology and Systematics 33: 589-639.

Rech AR, Rosa YBCJ and Silva HM (2010) Comportamento de dendróbio borboleta (Dendrobium phalaenopsis var. compactum C.T. White - Orchidaceae) sob diferentes níveis de sombreamento. Revista Agrarian 3: 84-87.

Takamura T and Miyajima I (1996) Colchicine induced tetraploids in yellow-flowered cyclamens and their characteristics. Scientia Horticulturae 65: 305-312.

Vichiato MRM, Vichiato M, Castro DM, Dutra LF, Pasqual M and Araújo
TS (2008) Bucha vegetal e fertilização organo-mineral no cultivo de Dendrobium nobile Lindl. Revista da Faculdade de Zootecnia, Veterinária e Agronomia 15: 34-42.

Vichiato MRM, Vichiato M, Castro DM, Dutra LF and Pasqual M (2007) Indução e identificação de tetraploides em Dendrobium nobile Lindl. (Orchidaceae). Revista Ciência Agronômica 38: 385-390.

Vilela XMS, Pasqual M, Villa F and Araújo AG (2010) Tipos de pseudobulbos e número de nós no enraizamento e brotação de Dendrobium nobile. Revista Agrarian 3: 1-7.

Zimmerman JK (1990) Role of pseudobulbs in growth and flowering of Catasetum viridiflavum (Orchidaceae). American Journal of Botany 77: 533-542. 